TranscUlturAl, vol. 9.2 (2017), 64-85.

http://ejournals.library.ualberta.ca/index.php/TC

\title{
Necessary Borders for Negotiation: The Role of Translation
}

\section{David ar Rouz \\ LIDILE, Rennes 2 University}

Translation is usually deemed to help bridge gaps but seldom thought of as a means of strengthening or, at least, highlighting borders. The present article uses the example of translations involving the Breton language in order to show that translation may favour negotiation by both helping negotiators to understand each other and having them recognise the social border that makes them different. The article explains firstly the author's understanding of borders and negotiation. Secondly, the case of translation from and into Breton is examined. And finally, the discussion is extended to the European institutions, where European language policy also illustrates the dual function of translation in negotiation. The example of Breton evidences that translation fosters social distinction, language development and cooperation. At the EU level, the same roles are assumed by translation services and they contribute moreover to the legitimacy of the institutions and to the exercise of democracy. Such a conclusion invites to consider translation as an adequate means to manage language and cultural differences, even compared to language learning. It may be used, then, to deal with pressing issues such as the current migration flows to Europe. 